\title{
The Mystique of the Frontal Lobes
}

\author{
By Francis Schiller
}

What we, for better or worse, call the lobes of the brain was in 1573 for the first time termed "prominences" by Costanzo Varolio ${ }^{1}$. He distinguished three: an anterior, a medial, and a posterior prominentia, circumscribing them by the surrounding bones and pointing out that to each one corresponds a ventricular cavity (later called "horn").

In 1664, Thomas Willis, disregarding Varolio's prominences, wrote that

... either Hemispere is ... subdivided into two Lobes, to wit, the Anterior and the

Posterior; between which a branch of the Carotidick Artery, being drawn like a bounding

River to both, distinguishes them as it were into Provinces ... ${ }^{2}$

Anatomically, then, Willis' anterior lobe comprises our frontal and parietal as one, while the posterior includes the temporal with the occipital. The dividing fissure accommodating the middle cerebral artery, that "bounding river", took its name from Francis Le Boe or Sylvius (1641) ${ }^{3}$.

Around the turn of the 18th century Varolio's three "prominences" became the four "lobules" of François Chaussier 4 . A "limbic lobe", made up of mesial frontal, temporal, and parietal elements was added by Broca in 1878, pertaining to non-primate mammals and primitive instinets ${ }^{5}$.

As to the importance of the head in general, early beliefs were divided. Aristotle thought of the brain merely in terms of a cooler of the blood. While the Chinese altogether ignored the brain, Eastern beliefs could not entirely disregard the importance of the head. A Tibetan frontal view of man, for example, depicts the five vital "wheels", or centers, in the regions of the genitals, the abdomen, the chest, the neck, and the head, respectively. Above the eyes "human personality is joined to the universe; it represents manas, i. e. intellect, reason and cognitive ability." ${ }^{6}$ For some primitive people, also no doubt impressed by its dominant position and its vital openings in front, the head was taboo ${ }^{7}$. To quote a non-scholarly example: Stanton Delaplane, the columnist writing for the San Francisco Chronicle, told of a missionary in Fiji who was clubbed to death when he tried to show the local chief how to use the comb he had brought him for a present ${ }^{8}$.

Better known is the long continued, worldwide art of trephining, practiced as far back as the stone age. Whether the indications were to cure headaches, insanity, and/or simply an expression of magical beliefs pertain- 
ing to this or an afterlife, is guess work. The best known of them, a preColumbian Inca skull from Peru, does show a frontal opening; but this location was by no means only one chosen for trephining ${ }^{9}$. It is likely that the dura was respected by all those trephiners. During the late Renaissance quacks would trephine the frontal skull pretending to cut out some stones with they had prepared for subsequent demonstration to the credulous mentally deranged ${ }^{10}$. (In the Philippines some such practice seems to have been revived more recently.) A non-invasive technique persisted well into the 19th century: infants' heads were tightly bandaged into a conical shape, the high forehead to impart to their owners the highest possible status in their lives ${ }^{11}$.

The Homeric world had made a certain distinction between thymos, referred to ongoing emotion or thought, located in the chest, and psyche, located in the head. The latter had to do with things more abstract and future-oriented, such as honor and survival after death, in connection with the belief that here was the place for producing semen ${ }^{12}$. The first unequivocal references to the brain as the organ of mind go back to Pythagoras or rather his disciple Alcmaeon in the 5th century B.C. Next, reason and emotion, as well as epilepsy, were emphatically referred to the brain in the forceful Hippocratic essay on The Sacred Disease ${ }^{13}$.

One might guess that the brain has from the beginning owed most of its mystique to its fore part, to its superficial relation with the eyes in particular. Vision is of all the senses the closest to conscious mind: keep your eyes closed and you are already half asleep. Here was the obvious first station for sights, smells and tastes to enter awareness, hence to incite or plan action. That incorporeal something, the animal spirit, was contained, stored, even possibly distilled, in a ventricle. And so it was the first and foremost cavity, the one we call the anterior or frontal horn which, from the bishops Nemesius and Poseidonius at the end of the fourth century A.D. and throughout the Middle Ages, played the role of the sensorium commune, the place for the initial elaboration of sensory impressions and immediate response, and for imagination, hence called the phantastikon. Going backwards from these twin cavities through the chain of third and fourth ventricle, such impressions underwent the process of judgment, to be stored as memories way aft. Clearly, the frontal cavity was given the leading role in mentation. It was the one to look "ahead", to the future ${ }^{14,15}$.

As early as 1614, Felix Platter of Basel presented at autopsy what must have been the first description of a frontal tumor, an anterior falx meningio- 
ma, to be specific. Vascular, the size of a medium large apple, wrapped in its own membrane, it was unattached to the brain, Platter wrote, leaving a dent as it was easily removed by hand. Situated above the corpus callosum, it had caused the patient's gradual dementia, apathy and hypersomnia over a period of two years, following a blow to the head three to four years earlier ${ }^{16}$.

The mystique of the frontal lobes was revived with the advent of the romantic era and phrenology. Franz Joseph Gall dared to break the current postulate that the brain as a whole was the organ of the mind. In his work published between 1810 and 1819 the areas denoting diverse mental "faculties" number 25. Of these, numbers 11 to 25 are crowded together in the frontal areas. For Gall all man's social assets or "higher" functions appear in front; all the lower instincts are relegated to the back of the brain ${ }^{17}$.

Was Gall unaware of his forerunner, Emmanuel Swedenborg? In the 1740 's that famous mystic conceived "little brains (cerebellula)", "areas", "centers", or "courts", and considered loss of imagination, memory, and thought the result of injury to the fore part of the brain. "The very will is weakened", Swedenborg added, "and the power of its determination blunted," because "the highest court of the cerebrum is among the topmost protuberances, or in the crown, where the highest lobe is." 18

Gall's opponents: Vicq d'Azyr, Rolando, Reil, Gratiolet, and especially Flourens, were dealing with structure on a background of comparative anatomy. As in lower mammals the anterior lobe is less developed, it must be concerned with intellectual function ${ }^{19}$. Altogether the anterior lobe was "the special workshop of thinking", and "directed toward the future"-views expressed for instance in 1826 by Burdach ${ }^{20}$. Meanwhile Bouillaud untiringly followed Gall's line by proclaiming both anterior lobes as the seat for words ${ }^{21}$. By 1861 the so-called "faculty" of speech, or at least the articulation of words, was localized in a particular frontal convolution-the third-by the surgeon Paul Broca, soon to be confined to the left hemisphere, at least in right-handed people ${ }^{22}$.

But a few years earlier, in 1848, a small explosion occurred in Vermont that was to shatter the old, and establish a new, kind of frontal lobe mystique: the "Yankee Crowbar Case" of Phineas P. Gage, aged 25. Actually not an angled crowbar but a straight, pointed rod, a "tamping iron" three feet, seven inches long, one-and-a-quarter inch in diameter, and weighing thirteen-and-a half pounds, was accidentally shot right through this railroad worker's left cheek, left anterior fossa, left prefrontal lobe and bone. Fragments of brain and blood were found both on the rod and on some rocks 
lying nearby. His landlord moreover had witnessed that the victim was ejecting brain matter from his mouth, and he confirmed the trajectory by sticking his finger through the patient's gaping frontal calvarium. So did Dr. J.M. Harlow, who had the "truly terrific" case published three months later ${ }^{23}$. All witnesses were astounded that Gage was only momentarily convulsed and unconscious, and at the end of a three-and-a quarter mile ride in an oxcart could mount a long flight of stairs and quip: "Doctor, here is business enough for you!" (An early manifestation of Witzelsucht?) Unlike most such cases at the time he survived four weeks of infection and edema leading to stupor. It was only a few years after his death, which occurred twelve-and-a-half years after the explosion, that the second paper by Harlow made the "crowbar case" internationally famous ${ }^{24}$. The 1870 's were tuned to cortical localization in general, the frontal lobe in particular. Especially Fritsch and Hitzig's 1870 discovery of an electrically excitable motor cortex was adding a new chapter to the book of frontal lobe mystique. It was now understood why the lesion incurred by Phineas Gage had not caused a hemiplegia or aphasia: it had only affected areas situated in front of those centers. Nevertheless the destruction of this "prefrontal" region had prevented Gage from returning to his job or from being his old self. He had spent his intervening years in listless travels, occasional jobs, to end up with his mother in San Francisco where he died in status epilepticus. There was no autopsy. A few years later his skull was exhumed at the behest of Dr. Harlow, and became a museum piece at Harvard University, together with the over one meter long projectile that had never left the side of its victim.

Search of the literature unearthed some similar examples including one as far back as Morgagni ${ }^{25}$. Soon a parallel to humans was also observed in the mental state of monkeys whose prefrontal lobes were beginning to be ablated in the 1870 's ${ }^{26}$. It was striking, "though difficult to state, in precise terms," as Ferrier cautioned. Some of the manifestations in the experimental animals were "apathy ... responding only to the ... impressions of the moment ... or varying listlessness with restless and purposeless wanderings to and fro ... while not actually deprived of ... observation."

At a meeting of German neurologists and psychiatrists in 1884 Hitzig agreed that "intelligence - or rather the store house of ideas-must be sought in all parts of the cortex, or rather in all parts of the brain." But "abstract thought necessarily requires special organs" and "for the time being I look for them in the frontal brain." ${ }^{27}$ And in 1890 Hughlings Jackson opined that "the highest or third level ... is made up of centres of the 
praefrontal lobes ... as they are the 'organ of the mind', or anatomical substrate of consciousness ... the acme of the evolution." ${ }^{28}$ Also in the 1890's Paul Flechsig in Leipzig was speaking of "association or co-agitation centers" as distinct from those of projection ... Disease of the frontal parts somehow alters the idea of one's own person (Persönlichkeitsgefühl) as being capable of deliberate action and of personal participation in external or internal events, to the point of their ultimate extinction." ${ }^{29}$ And a few years later he added that "the emotional basis of the consciousness of the self ... seems to me ... mainly a function of the prefrontal region ..." It was rather the organ of "social feelings" than "abstract thinking" and, in fact, "better developed in the female ... a point which may be very important for the psychology of sex." 30 (The marriage, as it were, of two mystiques: the prefrontal with the female.)

At the same time surgeons such as MacEwen, Godlee, Horsley, and von Bergmann ventured a therapeutic approach to bona fide lesions of the brain ${ }^{31}$. To these famous names we have to add a maverick: that compelling and compulsive Swiss asylum director (at Préfargier/Neuchâtel), Dr. Gottlieb Burckhardt. His aim was to reduce or abolish the factor producing verbal hallucinations by removing or disconnecting one or the other speech area in up to four sessions spaced by several months. While five patients did surprisingly well in that they became less disturbed and disturbing without becoming aphasic, his sixth patient did, and died in epileptic status on the sixth postoperative day ${ }^{32,33}$. Here the matter rested, except that in 1910 a renowned pioneer of neurosurgery, the Estonian L. Puusepp, made the first abortive attempt at severing frontal "association fibers" in three manicdepressive patients. He achieved too slight a benefit to persevere ${ }^{34}$.

Based on the writings of Oppenheim, Goldstein, Feuchtwanger, and Kleist in Germany, von Economo in Austria, Henri Claude in France, and Khoroshko in Russia, Egas Moniz, Professor of Neurology and Statesman in Lisbon, toyed with the idea of a surgical attack on the frontal lobes. In 1935 a turbulent meeting in London stung Moniz into action ${ }^{35}$. At that meeting Jacobsen showed almost the same effect that Ferrier half a century earlier had demonstrated in monkeys deprived of their frontal lobes: they did not throw a tantrum when frustrated ${ }^{36}$. Having secured the aid of a surgeon-Almeida Lima-Moniz was able, already in the following year, to report substantial benefits of frontal "leucotomy" in 14 psychotic patients suffering from intractable anxious agitation. Not really helped were the remaining six in this series of twenty, as they mainly suffered from delusions 
and hallucinations ${ }^{37}$. One year after Moniz' publication of 1936, another neurologist - Walter Freeman - had started the ball rolling in the U.S. His partner, James W. Watts, had earlier observed intussusception of the gut in monkeys following electrical frontal lobe stimulation ${ }^{38}$. After they had modified and simplified Moniz' method they finally turned frontal leucotomy, now termed lobotomy, into an office procedure ${ }^{39}$. The flood of tens of thousands of lobotomies done during the 1940's all over the world, not to speak of cortical excisions, was followed by a tide. Starting in the 1950 's, the critics were directing their own agression against surgical aggressiveness ${ }^{40}$, directed in turn against those aggressive personalities, called patients. The other curb to psycho-surgery was the advent of phenothiazine drugs. Surgery as a tranquillizer began to be mostly limited to stereotactic procedures aimed at the portion of the frontal lobes which in 1878 Broca had assigned to his limbic lobe, specifically the portion formed by the anterior cingulate gyrus.

As early as 1888, in a critical survey of the literature and in her own experience as a pathologist, Dr. Leonore Welt of Zurich and Geneva had already found that lesions of the mesio-orbital parts of the frontal lobes were largely responsible for the observed personality changes ${ }^{41}$.

Anatomically speaking, the connections of the frontal lobes, both transcortical and subcortical, afferent as well as efferent, are legion. Equally massive has been the psychological exploitation of pathological evidence, physiological experiment, and therapeutic effort to elucidate frontal lobe function. Rylander in Sweden ${ }^{42}$, Luria in the Soviet Union ${ }^{43}$, Fulton in the U.S. ${ }^{44}$, their collaborators and successors, have in essence confirmed Dr. Harlow's remarkable follow-up of the Phineas Gage case. Whereas loss or destruction of the prefrontal convexity leads to some memory and cognitive defects, the severed mesio-orbital connections, in addition to autonomicvisceral upsets, tend to reduce more basic attributes of the personality as they produce aimlessness as well as restlessness, apathy as well as loss of control. Hence the flippancy, the moria of such patients observed by Jastrowitz in $1888^{45}$, the Witzelsucht so called by Oppenheim in $1891^{46}$, the bulimia and obesity as well as the lewdness and hyper-sexuality seen in many of those subjected to psychosurgery. It relieves patients in chronic pain or at least they desist from worrying and complaining about it. Perseveration may express itself in the forced grasping and groping described in the 1920's by Schuster ${ }^{47}$. All in all the link with the future seems attenuated or broken. The harrassing question "what if ..." yields to a rhetorical "so what." 
In a recent monograph (1980) Joaquin Fuster has used the terms "temporal structuring of behavior" and "temporal integration" to summarize prefrontal lobe function ${ }^{48}$.

From the medieval speculation that linked the forward portion of the brain with imagination, to Burdach's belief that it is directed toward the future, and from there to the collective evidence that its role lies in the planning of behavior, the mystique of the frontal lobes has rested in the marvel of human foresight.

\section{References}

${ }^{1}$ Varolius, C.: Anatomiae sive de resolutione corporis humani libri IV. Frankfurt, Wechel \& Fischer, 1591, p. 131.

${ }^{2}$ Willis, T.: The Anatomy of the Brain and Nerves, 1681, Ed. W. Feindel, Classics of Neurology \& Neurosurgery Library, Birmingham, Alabama. 1983, p. 91 (Latin original 1664).

${ }^{3}$ Baker, F.: The two Sylviuses. An historical study. Bull. Johns Hopkins Hospital, 1909. 20: 329-339.

${ }^{4}$ Chaussier, F.B.: Exposition sommaire de la structure et des différentes parties de l'encéphale du cerveau. Paris, Barrois, 1807, p. 36-37.

${ }^{5}$ Broca, P.: Le grand lobe limbique et la scissure limbique dans la série des mammifères. Rev. d'Anthropol. $2^{\mathrm{e}}$ sér. vol. 1, pp.385-498, 1878.

6 Veith, I.: Medizin in Tibet. Leverkusen, Bayer, 1958 (?), p. 24.

${ }^{7}$ Frazier, J.: The (new) Golden Bough. Ed. Gaster, T.H. New York, Mentor Books, 1964, p. 145.

${ }^{8}$ Dellaplane, S.: Postcard from Fiji. Rainy day in Suva. San Francisco Chronicle. October 15, 1970.

9 Walker, A. E.: A history of neurological surgery. New York, Hafner, 1967, pp. 1-9.

${ }_{10}$ Valenstein, E.S.: The psychosurgery debate, scientific, legal, and ethical perspectives, 1980. San Francisco, Freeman, p. 16.

11 Broca, P.: Sur un mode peu connu de déformation toulousaine. Bull. d' Anthropol. 1878. $3^{\mathrm{e}}$ sér. t. II, pp.699-700.

12 Onians, R.B.: The origin of European thought about the body. Cambridge U.P. 1951.

${ }^{13}$ Hippocrates: The sacred disease. Transl. Jones, W.H.S., Cambridge, Mass. Harvard U.P. Vol.II, pp. 127-183.

${ }^{14}$ Bruyn, G. W.: The seat of the soul. In Rose, F.C. \& Byram, W. F. Historical Aspects of the neurosciences. New York Raven P. 1982, pp.83-98.

${ }^{15}$ Sudhoff, W.: Die Lehre von den Hirnventrikeln in textlicher und graphischer Tradition des Altertums und Mittelalters. Arch.f. Geschichte d. Med. 1913. 7: 148-205.

16 Platter, F.: Observationum ... libri tres. Basel, Koenig, 1614, p. 11.

17 Gall, F.J.: Anatomie et physiologie du système nerveux en général, et du cerveau en particulier. 1810-1819. Paris, Schoell, Atlas.

See Clarke, E. and Dewhurst, K.: An illustrated history of brain function. 1972. Berkeley, University of California, P. p. 92, fig. 114. 
${ }^{18}$ Swedenborg, E.: Three transactions on the cerebrum. A posthumous work. 1938. Transactions A. Swedenborg Scientific Assoc., Philadelphia. pp. 556-560; 583.

${ }^{19}$ Tiedemann, F.: Anatomie und Bildungsgeschichte des Gehirns im Foetus des Menschen nebst einer vergleichenden Darstellung des Hirnbaues in den Thieren. 1816. Nürnberg, Fein. pp. 146-147.

${ }^{20}$ Burdach, K.F.: Vom Baue und Leben des Gehirns. 1819-1826. Leipzig, Dyk, vol.3. Pp. 495-496; 557.

${ }^{21}$ Bouillaud, J. B.: 1825. Recherches cliniques propres a démontrer que la parole correspond à la lésion des lobules antérieurs du cerveau, et à confirmer l'opinion de M. Gall, sur le siège de l'organe du langage articulé. Arch. gén. Méd. 8; 25-45.

Idem 1848. Recherches cliniques propres a démontrer que le sens du langage articulé... résident dans les lobes antérieurs du cerveau. Bull. Aca. Roy. Méd. 13: 699-719; 778-808.

${ }^{22}$ Broca, P.: Remarques sur le siège de la faculté du langage articulé; suivies d'une observation d'aphémie (perte de la parole) 1861. Bull. Soc. anatom. 36: 330-357.

As a result Broca at one point went so far in the spirit of Gall as to localize judgment, reflexion, comparing and abstract thought in the frontal convolutions, relegating feelings, inclinations and passions to the temporal and parietal ones. At the same Time, in a racial context, Gratiolet, an opponent of cerebral localization otherwise, declared Caucasian frontal lobes predominantly developed, parietal ones in Mongolians, the occipital in "Ethiopians", i.e. Blacks; this assured control over the world to the former; indeed, this "fleur du cerveau» had a "superior physiological dignity" (Jules Soury: Le système nerveux central, structure et fonctions: histoire critique des théories et des doctrines. Paris, Carré et Naud, 1899, pp. 599-600).

${ }^{23}$ Harlow, J.M.: Passage of an iron rod through the head. Boston Med. Surg. J. 1848. 39: 389-393.

${ }^{24}$ Idem: Recovery from the passage of an iron bar through the head. Bull. Mass. Med. Soc. 1868. 2: 327-346.

${ }^{25}$ Pitres, A.: Recherches sur les lésions du centre ovale des hémispheres cérébraux étudiées au point de vue des localisations cérébrales. 1877, Paris, Delahaye.

${ }^{26}$ Ferrier, D.: The localisation of cerebral disease. 1879. New York, Putnam. p. 25.

${ }^{27}$ Hitzig, E.: VIIIth Meeting of Southwest German Neurologists \& Psychiatrists, 1884. Arch. f. Psychiatrie 15: 270-275.

${ }^{28}$ Jackson, J.H.: On convulsive seizures. 1890. In Selected writings: 1931. Ed. Taylor; J. London, Hodder \& Stockton. Vol.1, p. 414.

${ }^{29}$ Flechsig, P.E.: Gehirn und Seele. 1896. Leipzig, Veit. Pp. 24-26.

${ }^{30}$ Idem: Gehirnphysiologie und Willenstheorien. (Brain physiology and theories of volition.) 5th International Psychology Congress, Rome, 1905. Trans. Bonin, G.von: The cerebral cortex. 1960. Springfield, ILL. Thomas. Pp. 195-197.

31 Zülch, K. J.: Brain tumors, 1957. New York, Springer. Pp. 1-10. Also Walker, A.E. (Ed.): A history of neurological surgery. New York, Hafner. 1967.

${ }^{32}$ Burckhardt, G.: Über Rindenexcisionen, als Beitrag zur operativen Therapie der Psychosen. Zeitschr.f. Psychiatrie, 1899. 47: 463-348.

${ }^{33}$ Bach, C.: Nekrolog Dr. Gottlieb Burckhardt. Allg. Zschr. f. Psychiat. 1907, 64: 529-534.

${ }^{34}$ Puusepp, L.: Etat actuel et problèmes prochains sur la question du traitement des maladies mentales, Congrès International, Moscou, 1914. 
${ }^{35}$ Moniz, E.: Tentatives opératoires dans le traitement de certaines psychoses. 1936. Paris, Masson.

${ }^{36}$ Jacobsen, C. E., Wolfe, J.B. \& Jackson, T. A.: An experimental analysis of the functions of the frontal association areas in primates. 1935. J. Nerv. Ment. Dis. 82: 1-14.

37 Moniz, ref. 35, p. 210.

${ }^{38}$ Watts, J.W.: Influence of the cerebral cortex on gastrointestinal movements. J. Amer. Med. Ass., 1935, 104: 355-357.

${ }^{39}$ Freeman, W. and Watts, J.W.: Psychosurgery. Intelligence, emotion and social behavior following prefrontal lobotomy for mental disorders. 1942 Springfield, Ill., Thomas.

${ }^{40}$ Valenstein, E.S. (Ed.): The psychosurgery debate. Scientific, Legal and ethical persepctives. 1980. San Francisco, Freeman.

41 Welt, L.: Über Charakterveränderungen des Menschen infolge von Läsionen des Stirnhirns. Deut. Arch.f. klin. Med. 1888, 42: 339-390.

${ }^{42}$ Rylander, G.: Brain surgery and psychiatry. Aeta chir. Scand. 1941, 85: 213-234.

${ }^{43}$ Luria, A. R.: Higher cortical functions in man. Tr. Haigh, B. 1966. New York, Basik Books Pp. 5-22; 218-292.

${ }^{44}$ Fulton, J.F.: Physiologie des lobes frontaux et du cervelet; étude expérimentale et clinique. 1953. Paris, Masson.

45 Jastrowitz, M.: Beiträge zur Lokalisation im Grosshirn und über deren praktische Verwertung. Deut. med. Wschr. 1818. 14: 81-83.

${ }^{46}$ Oppenheim, H.: Zur Pathologie der Großhirngeschwülste. Arch. f. Psychiat. 1891. 22: $55-59$.

47 Schuster, P.: Zwangsgreifen und Nachgreifen. Zschr.f. d.ges. Neurol. u. Psychiat. 1923. 83: 586-609. Ibid. 1927, 108: 715-733.

${ }^{48}$ Furter, J.: The prefrontal cortex; anatomy, physiology and neuropsychology of the frontal lobes. 1980. New York, Raven P. pp. 125-142.

\section{Summary}

While the status of the brain as the organ of the mind remained controversial in the West throughout antiquity - and altogether ignored in Chineses tradition-the anatomical division by "prominences" began with Varolio in the 16th century and received lasting validity with F.B. Chaussier's four "lobules" in the early eighteenhundreds. Its frontal portion and cavity, lying above the eyes, had naturally suggested wakefulness, imagination, and the Aristotelian sensorium commune to medieval thinkers. Trephining, mock operations, and the binding of infants' heads to emphasize the forehead, exemplified magic beliefs in its superiority. Swedenborg, as well as Gall, revived the idea of a leading frontal lobe; for Burdach it was "directed toward the future." The "Yankee crowbar case" of Vermont, the discoveries of cerebral localizations for speech and motility from the second third of the 19th century on, underlined the importance of the frontal lobe, to be followed by a wave of surgical interventions here, designed to correct mental disorders and alleviate pain, peaking in the 1940 's. Before the turn of the century Dr. G. Burckhardt of the Préfargier (Neuchâtel) asylum had tried cortical excisions, and the pathologist Dr. Leonore Welt of Zurich and Geneva had collected old and new evidence of personality changes due to mesio-orbital frontal lobe lesions. Prefrontal activity may still be subsumed under the concept of "foresight." 


\section{Zusammenfassung}

\section{Das Geheimnis des Stirnhirns}

Während die Stellung des Gehirns als Geistesorgan in der Antike Kontroversen unterworfen war - in China wurde es sogar vollständig ignoriert -, begann seine anatomische Aufteilung in prominentiae im 16. Jahrhundert mit Varolio; zu Beginn des 19. Jahrhunderts wurde es von F.B.Chaussier in vier lobules (Läppchen) definitiv eingeteilt. Der frontale Anteil mit seiner Lage über den Augen legte im Mittelalter den Zusammenhang mit Aufmerksamkeit, Phantasie und dem Begriff des sensorium commune des Aristoteles nahe. Trepanationen, Scheinoperationen und das Bandagieren von Säuglingsschädeln zur Betonung einer hohen Stirn illustrieren den Glauben an die Magie seiner Überlegenheit. Swedenborg sowohl wie auch Gall ließen die Idee eines führenden Frontallappens aufleben: Burdach sah ihn als «der Zukunft zugewandt». Der "Yankee crowbar case" in Vermont (1848), die Entdeckungen der Hirnlokalisation bezüglich Sprache und Motilität, im zweiten Drittel des 19. Jahrhunderts begonnen, hoben die Bedeutung des Stirnlappens hervor. Es folgte die Flut von chirurgischen Eingriffen hier mit der Absicht, Geistesstörungen zu beheben und Schmerzen zu lindern: sie erreichte in den vierziger Jahren dieses Jahrhunderts ihren Höhepunkt. Dr. G. Burckhardt in der Irrenanstalt Préfargier (Neuchâtel) hatte bereits 1895 die ersten Rindenexzisionen unternommen; die Pathologin Dr. Leonore Welt, in Zürich und Genf, sammelte 1888 altes und neues Beweismaterial für Persönlichkeitsveränderungen auf Grund von mesio-orbitalen Läsionen. - Schließlich kann man auch heute präfrontale Aktivität unter dem Begriff der «Voraussicht» subsumieren.

Francis Schiller, M.D.

Department of the history of health sciences University of California

San Francisco CA 94143

U.S.A. 